\title{
Effect of Balance on Development Level of the Locomotor Capabilities of Kindergarten Children
}

\author{
Atradinal, Yudi Vetra*, Jonni, Oktarifaldi, Risky Syahputra, Romi Mardela, Syahrial Bakhtiar \\ Faculty of Sport Science \\ Padang State University \\ Padang, Indonesia \\ *yudivetra1989@gmail.com
}

\begin{abstract}
This research aims to see influence balanced against the level of development of children's locomotor abilities. The Population in this study were all PAUD students in the district Padang Pariaman, a random sampling technique totaling 42 children. The instrument used to obtain data about the balance of PAUD students is the MABC_2 subtest is balance while capability child locomotor is obtained through the Test of Gross Motor Development-2 (TGMD-2). Based on research results carried out, there is a balancing effect on the level the development locomotor abilities of a child with value $r_{\text {count }} 0,441>r_{\text {table }} 0,304$ and significant value (Sig) of 0,003 less than the probability of 0,05 . The results of this study show that level of ability development Padang Pariaman Regency PAUD student locomotor influenced by the balance they have.
\end{abstract}

Keywords-Balance. The capability of Development Level Locomotor

\section{INTRODUCTION}

Early Childhood Education (PAUD) in Indonesia has been led directly bye the government since 2010 [1] Law Number 20 of 2003 concerning the National Education System Article 1 Paragraph 14 states that Early Childhood Education (PAUD) is an effort aimed at coaching to children from birth until the age of six that done through providing educational stimuli to help physical growth and development and spiritually so that children have readiness to enter futher education. The range of early childhood according to Article 28 of the National Education System Law No. 20/2003 paragraph 1 is $0-6$ years [2].

To be able to help growth and development Early Childhood movements Government in Law No. 58 year 2009 has set standards that must be possessed by teachers and education staff at PAUD education level [3]. One of them is the teacher must have a good understanding of basic motion. Even though such is the knowledge and ability of the teacher still very low [4].

Basic mobility is seen as the initial foundation from the development and growth of the child's basic motion and will be needed in the future to carry out activities sports and other physical activity [5]. Data regarding basic movement skill of early childhood and school basic in Indonesia is still very limited and understanding regarding this matter is also very low [6].
Therefore it is very important to know the level of motion skills the basis for children in the future the learning program can be designed so that the basic movement skill of the child can be improved according to their age.

Australia, United Kingdom, United States America, Belgium,Scotland, South America and Asia in the past decade have been conduct research related to basic motion skills because it turns out that this basic movement skill is influential most aspects of their children's lives, you nama it development of cognitive abilities [6]. Cognitive ones caused by changes in the physiology of the human body. For example, increased levels of brain-derived neurotropic factors (BDNF) can facilitate learning and maintaining cognitive function with increase synaptic plasticity and function as an agent neuroprotective, which leads to increased activity neuroelectric and increased brain circulation [7].

Basic motion skill consist of locomotor (running, galloping, hopping, leaping, horizontal jump and sliding) and manipulative abilities (striking, stationary dribbling, catching, kicking, overhand throw, and underhand roll) [8]. Locomotor skills involve body movements and including skills such as running, skipping and jump [9]. Basically the locomotor ability is the ability a child has to be able to move from one point to another according to level development that they should have. Ability locomotor emphasizes gross motor skills which requires changing coordination movements as one-sided child movements or the other.

Motor skills and balance are the beginning of the achievement of physical development in childhood. Balance is a way to maintain the body in order to remain at the point of gravity determined by the feet, it could be static and dynamic equilibrium[10].

\section{LEVEL DEVELOPNT OF LOCOMOTOR ABILITY AND BALANCE}

\section{A. Level of Locomotor CapMEability Development}

Basic movement skills are very important for children early age is divided into two forms, namely locomotor and object control. Locomotor skills involve body movement and inculdes skills such as running, jumping around and jump [9]. Basically locomotor 
capabilities is the abiliy possessed by a child to can move from one point to another in accordance with the level the development tht they should have locomotor emphasizes gross motor skills which requires changing coordination movements as one-sided child movements or the other. Experience from locomotor activities performed on the past will effect control balance owned by children, for example pedestrians which has a better response to stimulation received while doing outdoor activities[11].

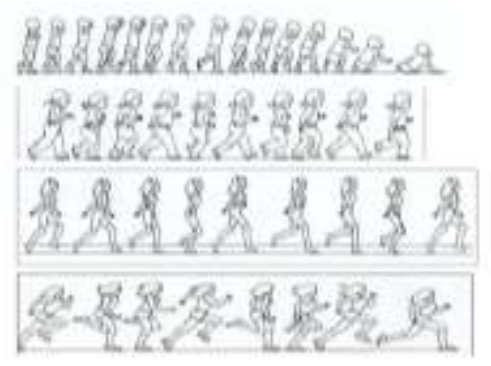

Image 1. Level of development run

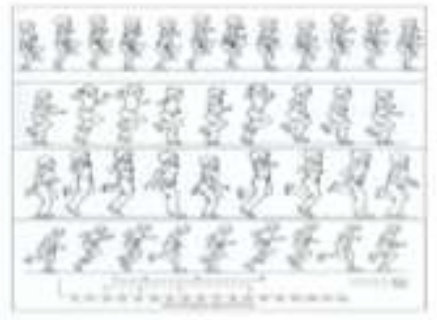

Image 2. Level of development hop

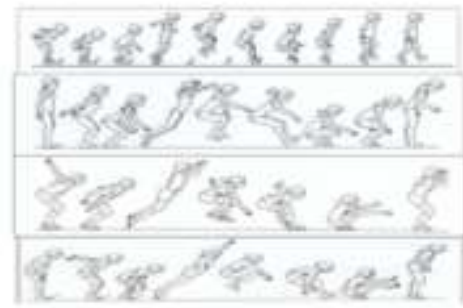

Image 3. Level of development jump

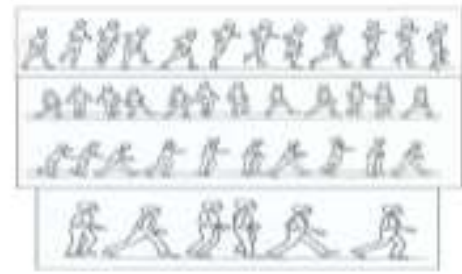

Image 4. Level of development gallop

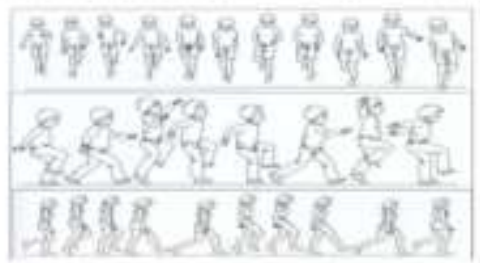

Image 5. Level of development skip

\section{B. Balance}

Motor skills and balance are the beginning of the achievement of physical development in childhood. Balance is a component needed for successful completion of fuctional activities including locomotor and manipulative skills in doing daily activities. For example playing running and jumping[12]. Balance is a basic ability that must be owned by a child during the growth stange and motor development which is a deep foundation do more complex movements. In addition, the balance of the child is also important for the development of motion functions in sports. Increased movement skills in children will reduce the risk of injury during physical activity in childrens[13].

The development of the balance element in children begins at birth and continues to develop until the age between 10 to 18 month, then more complex at preschool age [14]. The balance id divided into two namely static and dynamic balance. Static balance obtained when someone is silent [15]. Balance dynamic is obtained when a person can maintain his posture remained upright in a state of motion [16].

\section{DATA COLlECTION TEChNIQUE}

The instrument used to obtain data regarding the balance of PAUD students is a sub-test MABC_2 is balance while locomotor capabilities children are obtained through the Test of Gross Motor Development-2 (TGMD-2) consisting of running, jump on leg (hop), long jump (horizontasl jump), horse steps (gallops) and happt steps (skip).

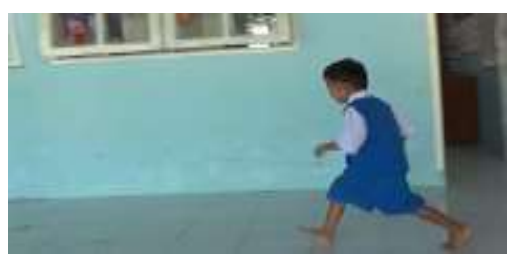

Image 6. Gallop illustration

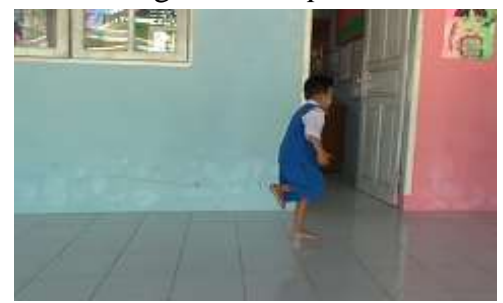

Image 7. hop illustration

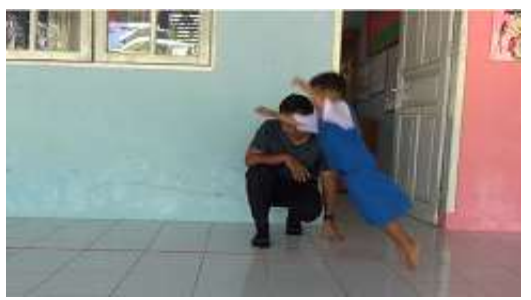


Image 8. jump illustration

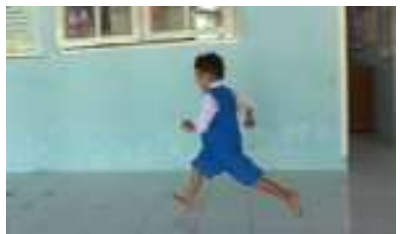

Image 9. run illustration

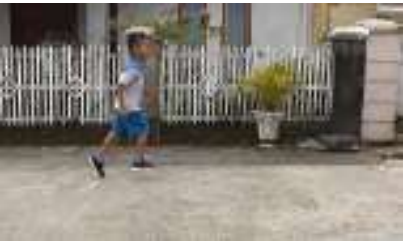

Image 10. skip illustration

IV.

USING THE TEMPLATE

Data on the level of development of students locomotor abilities PAUD in Padang Pariaman Regency were taken as much as 2 repetition times for all children for each skill tested. Data from the test is stored in video format. Grading the level of development of locomotor abilities this is based on the INDO-SKIP Training sheet. Then for children by 1 time an experiment and this data is stored in the form of a test sheet. This test is given to children aged 5 to 6 years. Number of students who are involved were 42 people consisting of 24 woman and 18 men.

\section{CONCLUSIONS}

Data balance and level of development ability PAUD students locomotor in Padang Pariaman Regency using instruments that have been standardized and are used by many countries the world. This research involves as much 42 PAUD students. Data obtained in research it has a pretty good quality because it uses valid instruments and all skill criteria locomotor capabilities that are judged to have been coded by the expert. In the future we will try to apply the model learning in accordance with the PAUD curriculum in Indonesia.

\section{REFERENCES}

11] Famelia, Ruri., Tsuda, Emi., Bakhtiar, Syahrial \& Goodway, Jacqueline D. "Relationships Among Perceived and Actual Motor Skill Competence and Physical Activity in Indonesian Preschoolers". Journal of Motor Learning and Development, 2018, 6, S403-S423 https://doi.org/10.1123/jmld.2016-0072 (C) 2018 Human Kinetics, Inc. Original Research

[2] Undang-Undang Republik Indonesia Nomor 20 Tahun 2003 Tentang Sistem Pendidikan Nasional. 2003.pp.20-121.
[3] Peraturan Menteri Pendidikan Nasional Republik Indonesia Nomor 58 Tahun 2009 Tentang Standar Pendidikan Anak Usia Dini.2009.pp.10--130

[4] Goodway, Jacqueline D., Famelia, Ruri \& Bakhtiar, Syahrial. "Future Directions in Physical Education \& Sport: Developing Fundamental Motor Competence in the Early Years Is Paramount to Lifelong Physical Activity". Asian Social Science; Vol. 10, No. 5; 2014 ISSN 1911-2017 E-ISSN 1911-2025 Published by Canadian Center of Science and Education

[5] D.L., Gallahue, J.C Ozmun,. and , J. Goodway. "Understanding Motor Development Infants, Children, Adolescents, Adults". McGraw-Hill, New York. 2012.pp.10-15.

[6] Bakhtiar, Syahrial. "Fundamental Motor Skill among 6-Year-Old Children in Padang", West Sumatera, Indonesia. Asian Social Science; Vol. 10, No. 5; 2014 ISSN 1911-2017 E-ISSN 1911-2025 Published by Canadian Center of Science and Education.

[7] C. Hillman, , K. Erickson, and A. Kramer. "Be smart, exercise your heart: Exercise effects on brain and cognition". Nature Reviews Neuroscience, 9, 2008.pp.58-65. doi:10.1038/nrn2298.

[8] Ulrich, D. A. "The Test of Gross Motor Development (2nd ed.)". PRO-ED, Austin, TX, USA. 2000.pp.12-24

[9] Ajmol Ali, Deborah Pigou, Linda Clarke, Claire McLachlan. "Literature Review on Motor Skill and Physical Activity in Preschool Children in New Zealand". Advances in Physical Education, 2017, 7, 10-26 http://www.scirp.org/journal/ape ISSN Online: 2164-0408 ISSN Print: 2164-0386

[10] Renato de Souza Melo, Sônia Elvira dos Santos Marinho, Maryelly Evelly Araújo Freire, Robson Arruda Souza, Hélio Anderson Melo Damasceno, Maria Cristina Falcão Raposo. "Static And Dynamic Balance Of Children And Adolescents With Sensorineural Hearing Loss". DOI: 10.1590/S1679-45082017AO3976. Creative Commons Attribution 4.0 International License. einstein. 2017;15(3):262-8.

[11] Marko Nardini, Dorothy Cowie. "The development of multisensory balance, locomotion, orientation and navigation. In book: Multisensory Development", Chapter: 6, Publisher: Oxford University Press, Editors: Andrew J. Bremner, David J. Lewkowicz, and Charles Spence. 2012pp.112-126.

[12] Mary Rose Franjoine, Nancy Darr, Sharon L. Held, Karen Kott, \& Brenda L. Young. "The Performance of Children Developing Typically on the Pediatric Balance Scale. Pediatric Physical Therapy". Wolters Kluwer Health|Lippincott Williams \& Wilkins and Section on Pediatrics of the American Physical Therapy Association. Unauthorized reproduction of this article is prohibited. 2010.pp.4577.

[13] Devinder Kaur Ajit Singh, Nor Najwatul Akmal Akmal Ab Rahman, Roslee Rajikan, Asfarina Zainudin, Nor Azlin Mohd Nordin, Zainura Abdul Karim, Yeap Hui Yee. "Balance and Motor Skills among Preschool Children Aged 3 to 4 Years Old". Malaysian Journal of Medicine and Health Sciences (ISSN 1675-8544); Vol. 11 (1) Januay 2015: 63-68.

[14] Cillin Condon dan Katie Cremin. "Static Balance Norms in Children". Published online in Wiley Online Library (wileyonlinelibrary.com) DOI: 10.1002/pri.1549. Physiother. Res. Int. (2013) (C) 2013 John Wiley \& Sons, Ltd.

[15] Habib Z, Westcott S. Assessment of anthropometric factors on balance tests in children. Pediatr Phys Ther 1998: 10:101-109

[16] E, Bressel Yonker JC, Kras J, Heath EM. Comparison of static and dynamic balance in female collegiate soccer, basketball, and gymnastics athletes. J Athl Train 2007: 42 (1):42-6. 